\title{
Differential Expression Profiling of Myogenic Regulatory Factor Genes in Postnatal Longissimus dorsi Muscle of Indigenous and Large White Yorkshire Breeds of Pigs
}

\author{
Cammey $^{1}$, Simrinder Singh Sodhi ${ }^{1 *}$, R.S. Sethi ${ }^{1}$ and Ramneek ${ }^{2}$ \\ ${ }^{1}$ Department of Animal Biotechnology, College of Animal Biotechnology; Guru Angad Dev Veterinary and \\ Animal Sciences University, Ludhiana, INDIA \\ ${ }^{2}$ Department of Microbial and Environmental Biotechnology, College of Animal Biotechnology; Guru Angad Dev Veterinary and \\ Animal Sciences University, Ludhiana, INDIA \\ *Corresponding author: SS Sodhi; E-mail: simrindersodhi@gmail.com
}

Received: 05 Nov., 2020

Revised: 09 Jan., 2021

Accepted: 29 Jan., 2021

\begin{abstract}
Pigs form a very important component of the Indian livestock. It has immense potential to ensure nutritional and economic security for the weaker sections of the society. Pork is a nutritious food that is commonly consumed worldwide. The current study was planned to investigate the distinction in the relative expression of myogenic regulatory factors (MRF) genes $(M y o D$, Myf5, Myf6, Pax7 and Pax3) and their role in the postnatal myogenesis Longissimus dorsi muscles of indigenous and Large White Yorkshire (LWY) breeds. These genes help in muscle differentiation and regeneration of skeletal muscles. MyoD has shown significantly $(P<0.05)$ higher quantitative transcript levels in indigenous pigs than in LWY. There is no significant difference in the transcript levels of Myf5 and Myf6 have been observed in the indigenous pigs whereas both the genes have shown significantly $(P<0.05)$ higher quantitative transcript levels in LWY. Further, no statistically significant $(\mathrm{P}<0.05)$ difference for $P a x 3$ and $P a x 7$ have been recorded for both the breeds. The current study on relative expression of transcript levels of MRFs in LWY and indigenous pigs presents them as candidate genes for body growth rate. The current study will aid in understanding the genetic basis for myogenesis in postnatal stage. Moreover, it may act as steppingstone for the identification of marker genes related to body growth and meat quality in indigenous breeds.

\section{HIGHLIGHTS}

(0 We studied differential expression of myogenic regulatory factor genes in postnatal Longissimus dorsi muscle of indigenous and Large White Yorkshire breeds of pigs

(0 The genes under current study will help in muscle differentiation and regeneration of skeletal muscles.

(0 The current study will aid in understanding the genetic basis for myogenesis in postnatal stage.
\end{abstract}

Keywords: Indigenous, MyoD, Myf5, Myf6, $\operatorname{Pax} 7, \operatorname{Pax} 3$

Pigs form a very important component of the Indian livestock. Pigs are generally raised by economically weaker section of the society which not only provide them with a better nutritional support but also serves as an important source of livelihood (Sulabh et al., 2017). As a cheap source of healthy animal protein pigs can meet the requirement for the weaker section of the society (Chhabra and Samantaray, 2013). Pig as compared to other livestock species has a great potential to contribute to faster economic return to the farmers due to better-feed conversion efficiency, early maturity and short generation interval. Ten indigenous pig breeds have been recognized in India (Kaur et al., 2020). The larger population consisting

How to cite this article: Cammey, Sodhi, S.S., Sethi, R.S. and Ramneek (2021). Differential expression profiling of myogenic regulatory factor genes in postnatal Longissimus dorsi muscle of indigenous and large white Yorkshire breeds of pigs. J. Anim. Res., 11(1): 11-17. Source of Support: None; Conflict of Interest: None 
of an un-descript type of pigs usually have less production ability (Sulabh et al., 2017). However, implementation of proper cross-breeding programmes development of popular and locally acceptable new breeds by crossing indigenous pigs with high yielding exotic breeds have resulted in an expansion in the popularity of pig rearing. Acceptance of the pig meat by the society has resulted in an increase in the demand.

In Punjab there are more than 200 piggery farmers having more than 30,000 pigs. According to GIO there is 0.03 million pigs population. Indigenous breeds of pig have poor growth rate, small litter size but the quality of pork is high. Pork from indigenous breed is tender and juicy (Sodhi et al., 2014). LWY has higher growth rate, better feed efficiency and high prolificacy rate. Muscularity and growth rate are among the prime economic traits for meat animals. Clear evidences have established that size of muscle fiber; number of fibers; fiber area and density of fibers are in close vicinity with the traits related to meat quality (Hwang et al., 2010).

Muscle regulatory factors (MRFs), are components of basic helix- loop- helix (bHLH) family and are involved in the myogenesis. Myogenesis and transcription of the genes specific for muscles is controlled by bHLH transcription factors (te Pas et al., 2007). Myogenic determination factor $(M y o D)$, myogenic factor-6 (Myfo) and myogenic factor-5 $(M y f 5)$ are the multifaceted members of MRF. $M y o D$ is implicated in the differentiation of skeletal muscles. It has been reported that $M y o D$ and paired box transcription factor-7 (Pax7) co-express in the actuated satellite cells (Xu et al., 2018). Pax7 induces self-regeneration of satellite cells and can be one of the candidate genes to affect the feisty stages of post-natal muscle growth in the pig (Patruno et al., 2007). Myf6 has been recognized for encrypting bHLH transcription factors and significantly affect the differentiation of muscle fibers (WyszynskaKoko and Kuryl, 2004). Further, it has tendency to express more in the adult skeletal muscle tissue of lean breeds (te Pas et al., 2000). Earlier reports suggested that anomaly in the cleavage of MRFs can have deep effects on the growth of skeletal muscles (Allen et al., 2010). Although the relationship between the weight of carcass, characteristics of muscle fiber and traits related with pork quality is not fully understood, but still muscle mass and the weight of the pigs are related to fiber composition (Yang and Kim, 2006).
Meager reports are available on comparative transcriptomic studies on indigenous breeds of pigs. Therefore, the relative analysis of transcript levels of MRFs in the postnatal myogenesis of longissimus dorsi muscles in indigenous pigs and LWY breeds have been targeted in the current study, so that these can be pondered as candidate genes for muscle growth during the breed improvement programs.

\section{MATERIALS AND METHODS}

The current study was carried out at (Department of Animal Biotechnology and College of Animal Biotechnology) Guru Angad Dev Veterinary and Animal Sciences University (Ludhiana).

\section{Collection of tissues}

In the current study, six each pure breed adult animals each from Indigenous and LWY breeds were chosen. The longissimus $d o r s i$ muscle tissue samples between $12^{\text {th }}$ and $13^{\text {th }}$ rib spaces were harvested instantly following the slaughter from slaughterhouse. Tissue samples were transported immediately from slaughterhouse to lab in RNA later solution and dry ice. Later, the samples were later kept at $-80^{\circ} \mathrm{C}$ till their further use for RNA extraction. Tips and eppendrfoff's tubes were treated with Di-ethyl pyro-carbonate (DEPC).

The RNA was extracted from the fragmented frozen longissimus dorsi muscle $(120 \mathrm{mg})$ of adult animals of both the breeds. TRIzolTM (QIAZEN) reagent was used to isolate RNA from longissimus dorsi muscle. The tissue was homogenized by mixing with $2.0 \mathrm{ml}$ of TRIzol and $400 \mu \mathrm{l}$ of chloroform. Then, isopropanol (HIMEDIA) was subsequently used to precipitate the homogenized tissues. Later, $1 \mathrm{ml}$ of $75 \%$ ethanol was used to wash the precipitated pellet. Immediately, followed by extraction, isolated samples of RNA were stored at $-80^{\circ} \mathrm{C}$. The genomic DNA impurities from RNA samples $(25 \mu \mathrm{g})$ were eliminated with the RNase-free DNase set (QIAGEN, Hilden, Germany) and RNA was purified with the RNeasy mini kit according to the manufacturer's guidelines (QIAGEN, Hilden, Germany). The quantity of RNA was assessed by the thermo scientific Nanodrop one and quality was judged by automated capillary gel electrophoresis according to manufacturer's guidelines (Agilent Technologies Ireland, Dublin, Ireland). The ratios 
of $28 \mathrm{~S} / 18 \mathrm{~S}$ for the RNA samples were between 1.8 and 2.0 and the values for the integrity of RNA ranged from 8.0 to 10.0 .

\section{Quantitative Real Time PCR (qRT-PCR)}

Primers for the qRT-PCR were constructed by the online Primer-3 software (Rozen and Skaletsky, 2000) and the information of the primers has been enlisted in Table 1 . For the quantitative evaluation of mRNA transcript levels of MyoD, Myf5, Myf6, Pax 3 and Pax 7 genes; in indigenous and LWY, real-time qRT-PCR was performed using an (BIO RAD model CFX96 ${ }^{\mathrm{TM}}$ Optics Module real time PCR). To determine the quantity of transcripts of target genes EvaGreen (Biotium, USA) dye was used. Triplicate samples were used for the quantification by following the amplification conditions i.e. $95{ }^{\circ} \mathrm{C}$ for $10 \mathrm{~min}$ (initial denaturation), and then 39 cycles of $95^{\circ} \mathrm{C}$ for $15 \mathrm{sec}$ (denaturation) followed by $60{ }^{\circ} \mathrm{C}$ for $1 \mathrm{~min}$ (annealing and extending). The efficiency of real-time PCR was defined by the standard curve method. The amplified transcript levels of the target genes were compared with that of the $\beta$-actin, an endogenous control (Wang et al., 2003). mRNA transcript levels were quantified by the comparative $C_{T}$ method. The results in terms of relative expressions have been expressed after normalising with the transcript levels of the endogenous reference (Erkens et al., 2006; Van Poucke et al., 2001).

\section{Statistical analysis of the differential expression patterns of the MRFs}

Statistical analysis of the differential expression patterns of the MRFs was done using ANOVA. The values have been expressed as mean \pm SEM. $P<0.05$ has been set as statistical level of significance and subsequently Tukey's btest was performed for analyzing the level of significance.

\section{RESULTS AND DISCUSSION}

Relative quantitative transcript levels of MyoD, Myf5, Myf6, Pax7 and Pax3 after their normalization with the transcript levels of the endogenous reference $\beta$-actin, have been investigated through Real Time qRT- PCR. In the present study, MyoD displayed significantly $(P<0.05)$ higher quantitative transcript level in indigenous pigs than in LWY (Fig. 1, Table 2).

Both Myf6 and Myf5 did not indicate any statistically significant difference among themselves in the respective breeds during postnatal development (Fig. 1). Further, a statistically significant $(P<0.05)$ higher expressions have been observed in the LWY as compared to indigenous pigs (Table 3 and Table 4). No statistically significant difference in the transcript levels of both Myf6 and Myf5 between the breeds during postnatal development has been supported with the findings in the knockout mouse with $M y o D$ and Myf6 or Myf5 (Kassar-Duchossoy et al., 2004). Moreover, significantly similar transcript levels of

Table 1: Primer sequences of $M y o D, M y f 5, M y f 6, \operatorname{Pax} 3, \operatorname{Pax} 7, \beta$ - actin for PCR

\begin{tabular}{|c|c|c|c|c|}
\hline Primer & Primer Sequence & Product Size & $\mathbf{T m}$ & Gene bank ID \\
\hline \multirow[t]{2}{*}{ MyoD } & F 5'-TGCAAACGCAAGACCACTAA - 3' & $127 \mathrm{bp}$ & 55 & NM_001002824.1 \\
\hline & R 5'- GCTGATTCGGGTTGCTAGAC -3' & & & \\
\hline \multirow[t]{2}{*}{$\operatorname{Pax} 7$} & F 5' - GGCAGAGGATCTTGGAGACA - 3' & $144 \mathrm{bp}$ & 55 & AY653213.1 \\
\hline & R 5' - TGGGTGGGGTTTTCATCAAT - 3' & & & \\
\hline \multirow[t]{2}{*}{ Myf5 } & F 5' - CCGACACAGCTTGTGGAATA - 3' & $128 \mathrm{bp}$ & 55 & XM_001924362.2 \\
\hline & R 5' - GCCAATCAACTGATGGCTTT - 3' & & & \\
\hline \multirow[t]{2}{*}{ Myf6 } & F 5' - ATCTTGAGGGTGCGGATTTC - 3' & $108 \mathrm{bp}$ & 62 & XM_003481764 \\
\hline & R 5'- CAATGTTTGTCCCTCCTTCCT - 3' & & & \\
\hline \multirow[t]{2}{*}{ Pax3 } & F 5' - ATCGGCTAATCCTGACACATGC-3' & $130 \mathrm{bp}$ & 54 & AY579430.1 \\
\hline & R 5' - ACGGTGGGAAACTTTTGATG - 3' & & & \\
\hline \multirow[t]{2}{*}{$\beta$ - actin } & F 5'- GACATCCGCAAGGACCTCTA - 3' & $157 \mathrm{bp}$ & 60 & XM_003124280 \\
\hline & R 5'- ACACGGAGTACTTGCGCTCT - 3' & & & \\
\hline
\end{tabular}


Table 2: Validation of expression of MyoD mRNA using real time PCR (SYBR green)

\begin{tabular}{|c|c|c|c|c|c|}
\hline Group & $\begin{array}{l}\text { MyoD } \\
\left.\text { (Average } \mathrm{C}_{\mathrm{t}}\right)\end{array}$ & $\begin{array}{l}\beta \text {-actin } \\
\left(\text { Average } C_{t}\right)\end{array}$ & $\begin{array}{l}\Delta \mathrm{CT}\left(\mathrm{C}_{\mathrm{t}} M y o D-\right. \\
\left.\mathrm{C}_{\mathrm{t}} \beta \text {-actin }\right)\end{array}$ & $\begin{array}{l}\Delta \Delta \mathrm{CT} \\
\Delta \mathrm{C}_{\mathrm{t}} \text { of treated }-\Delta \mathrm{C}_{\mathrm{t}} \text { of } \\
\text { untreated) }\end{array}$ & Fold change \\
\hline LWY & $28.72 \pm 0.82$ & $22.47 \pm 0.18$ & $6.25 \pm 0.75$ & $0 \pm 0.75$ & 1 \\
\hline Indigenous & $31.48 \pm 1.65$ & $22.65 \pm 0.16$ & $8.83 \pm 1.01$ & $-0.64 \pm 1.01$ & $1.56^{*}$ \\
\hline
\end{tabular}

Values are Mean \pm SE. Mean's bearing superscript *differ significantly at $\mathrm{p}<0.05$.

Table 3: Validation of expression of Myf5 mRNA using real time PCR (SYBR green)

\begin{tabular}{|c|c|c|c|c|c|}
\hline Group & $\begin{array}{l}\text { Myf5 } \\
\left(\text { Average } \mathrm{C}_{\mathrm{t}}\right)\end{array}$ & $\begin{array}{l}\beta \text {-actin (Average } \\
\left.C_{t}\right)\end{array}$ & $\begin{array}{l}\Delta \mathrm{CT}\left(\mathrm{C}_{\mathrm{t}} M y f 5-\right. \\
\left.\mathrm{C}_{\mathrm{t}} \beta \text {-actin }\right)\end{array}$ & $\begin{array}{l}\Delta \Delta \mathrm{CT} \mid \\
\Delta \mathrm{C}_{t} \text { of treated }-\Delta \mathrm{C}_{\mathrm{t}} \text { of } \\
\text { untreated) }\end{array}$ & Fold change \\
\hline LWY & $26.68 \pm 1.166$ & $22.58 \pm 0.17$ & $4.1 \pm 1.12$ & $0 \pm 1.12$ & 1 \\
\hline Indigenous & $33.29 \pm 0.22$ & $19.37 \pm 0.04$ & $13.92 \pm 3.90$ & $6.07 \pm 0.3 .90$ & $0.014 *$ \\
\hline
\end{tabular}

Values are Mean \pm SE. Mean's bearing superscript *differ significantly at $\mathrm{p}<0.05$.

Table 4: Validation of expression of Myf6 mRNA using real time PCR (SYBR green)

\begin{tabular}{|c|c|c|c|c|c|}
\hline Group & Myf6 (Average $\mathrm{C}_{\mathrm{t}}$ ) & $\begin{array}{l}\beta \text {-actin (Average } \\
C_{t} \text { ) }\end{array}$ & $\begin{array}{l}\Delta \mathrm{CT}\left(\mathrm{C}_{\mathrm{t}} M y f 6-\right. \\
\left.\mathrm{C}_{\mathrm{t}} \beta \text { - actin }\right)\end{array}$ & $\begin{array}{l}\Delta \Delta C T \\
\Delta C_{t} \text { of treated }-\Delta C_{t} \text { of } \\
\text { untreated) }\end{array}$ & Fold change \\
\hline Indigenous & $34.92 \pm 0.63$ & $24.40 \pm 0.05$ & $10.52 \pm 0.16$ & $7.74 \pm 0.15$ & $0.0046^{*}$ \\
\hline
\end{tabular}

Values are Mean \pm SE. Mean's bearing superscript *differ significantly at $\mathrm{p}<0.05$.

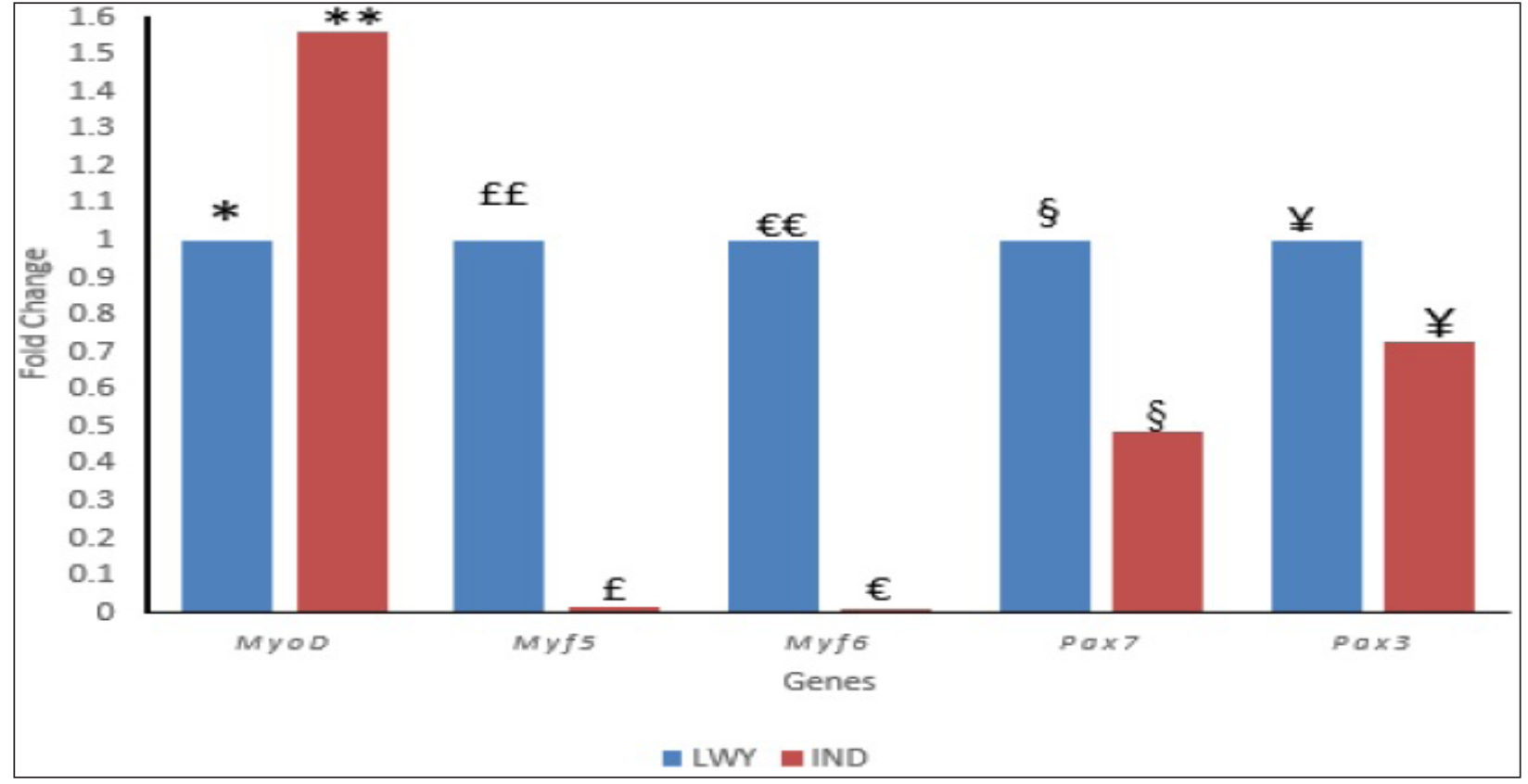

Fig. 1: Relative transcript level (RQ) of MyoD, Myf5, Myf6, Pax7, and Pax3 in MRFs in postnatal longissimus dorsi muscles of Large White Yorkshire and indigenous pigs. $R Q$ has been normalized with the transcript levels of the endogenous references ( $\beta$ - actin) and keeping Large White Yorkshire as reference sample. Bars with different superscripts show significant differences in the transcript levels between the two breeds $(\mathrm{p}<0.05)$. Values are expressed as mean $\pm \mathrm{SEM}$ 
Myf5 and Myf6 genes in both the breeds indicate towards their close vicinity on SSC5. It is a well-documented fact that postnatal muscle growth in pigs is a collective result of association of satellite stem cells and hypertrophic mechanisms (Ishido et al., 2008). In single, double and triple mutant mice an up- stream activity of Myf6 with MyoD gene has been reported (Ropka-Molik et al., 2011). Myf6 is a plentifully expressed myogenic factor in the postnatal muscles and it quantitatively dominates over the transcripts of $M y o D$ family (White et al., 2010). The raised Myf6, mRNA and protein levels are related with the bigger myofiber size (Yin et al., 2013) and higher mean fiber area (Hespel et al., 2001). Myf6 has dominant expression levels in postnatal mature fibers (Maak et al., 2006). Polymorphism in the promoter region and exon 1 of $M y f 6$ is reported to be significantly related with the weight of longissimus dorsi muscle and daily weight gain (Wyszynska-Koko and Kuryl, 2004). Significantly similar transcript levels of $M y f 6$ in both the breeds may help in explaining the presence of fast-growing fiber types in LWY and better meat quality related properties of indigeneous.

Non-significantly, lower expression of Pax3 and Pax7 have been recorded in indigenous pigs (Fig. 1 Table $5 \&$ Table 6). These genes are reported to play critical role during fetal development and their proteins are essential for renewal and maintenance of stem cells. Moreover, it has been reported that levels of $\operatorname{Pax} 7$ transcript depend on type of muscle and breed (Ropka-Molik et al., 2011). Higher muscularity in Pietrain pigs is suggestive of higher expression of MyoD and Pax7 (Ropka-Molik et al., 2011). Such findings are parallel to our results, since the animals of LWY breed showed higher transcript levels than indigenous pigs which may support higher skeletal muscle regeneration potential of LWY pigs. That's why these genes are targeted as candidate genes for meat production in pigs.

Myofibrils encompass actin and myosin as the main proteins in thin and thick filaments (Zhang, 2009). Major protein in the thick filaments which influences the type of muscle fiber is myosin. The type of the muscle fibers is reported to be responsible for the color, stability, and tenderness of meet.

\section{CONCLUSION}

Enhancements in body growth rate and quality of pork are amongst the top urgencies of breeding plans. Indigenous breeds have good meat quality, high tenderness and juiciness but lags in body growth rate as compare to western breeds. Constant fall in the quality and carcass characteristics have guided the breeders to improve such parameters. LWY is a rapidly-growing breed with large heavy muscular body and higher muscle fibers in the carcass with respect to indigenous breeds.

Table 5: Validation of expression of Pax7 mRNA using real time PCR (SYBR green)

\begin{tabular}{|c|c|c|c|c|c|}
\hline Group & $\begin{array}{l}\operatorname{Pax} 7 \\
\left(\text { Average } C_{t}\right)\end{array}$ & $\beta$-actin (Average $C_{t}$ ) & $\begin{array}{l}\Delta \mathrm{CT}\left(C_{t} \operatorname{Pax} 7-\right. \\
\left.\mathrm{C}_{\mathrm{t}} \boldsymbol{\beta} \text {-actin }\right)\end{array}$ & $\begin{array}{l}\Delta \Delta \mathrm{CT} \\
\Delta \mathrm{C}_{\mathrm{t}} \text { of treated }-\Delta \mathrm{C}_{\mathrm{t}} \text { of } \\
\text { untreated) }\end{array}$ & Fold change \\
\hline$\overline{L W Y}$ & $27.18 \pm 4.36$ & $23.46 \pm 0.24$ & $3.72 \pm 4.43$ & $0 \pm 4.34$ & 1 \\
\hline Indigenous & $23.51 \pm 2.50$ & $19.21 \pm 0.23$ & $4.3 \pm 2.30$ & $1.05 \pm 2.30$ & 0.48 \\
\hline
\end{tabular}

Values are Mean \pm SE. Mean's bearing superscript *differ significantly at $\mathrm{p}<0.05$.

Table 6: Validation of expression of Pax3 mRNA using real time PCR (SYBR green)

\begin{tabular}{lllll}
\hline Group & $\boldsymbol{P a x 3}\left(\right.$ Average $\left.\mathbf{C}_{\mathbf{t}}\right)$ & $\boldsymbol{\beta}$-actin (Average $\left.\mathbf{C}_{\mathbf{t}}\right)$ & $\begin{array}{l}\Delta \mathbf{C T}(\boldsymbol{C} \boldsymbol{P a x 3}- \\
\mathbf{C}_{\mathbf{t}} \boldsymbol{\beta} \text {-actin) }\end{array}$ & $\begin{array}{l}\Delta \Delta \mathbf{C T} \mid \\
\Delta \mathbf{C}_{\mathbf{t}} \text { of treated }-\Delta \mathbf{C}_{\mathbf{t}} \text { of } \\
\text { untreated) }\end{array}$ \\
\hline LWY & $27.14 \pm 1.37$ & $22.52 \pm 0.09$ & $4.62 \pm 1.35$ & $0 \pm 1.35$ \\
Indigenous & $26.43 \pm 1.36$ & $21.91 \pm 0.27$ & $4.52 \pm 1.43$ & $0.45 \pm 1.43$ \\
\hline
\end{tabular}

Values are Mean \pm SE. Mean's bearing superscript $*$ differ significantly at $\mathrm{p}<0.05$. 
Our study on the comparative quantitative transcript levels of MRFs in LWY and indigenous pigs introduced them as candidate genes which are associated with body growth and quality of pork. Till now very few studies covering transcript richness of the MRFs in indigenous pigs have been performed. Current experimental study is one of the innovator expression studies in indigenous pigs. Findings of current study can be useful in understanding the genetic basis for myogenesis in postnatal adult muscles of indigenous pigs and in the breeds with low meat fat ratio. These findings can be utilized as the basis to plan further researches to completely understand the detailed signaling pathways for the transcriptional activation of target genes.

\section{REFERENCES}

Allen, N.S. 2010. Photochemistry and photophysics of polymeric materials. John Wiley \& Sons.

Carvajal, J.J., Keith, A. and Rigby, P.W. 2008. Global transcriptional regulation of the locus encoding the skeletal muscle determination genes Mrf4 and Myf5. Genes Dev., 22(2): 265-276.

Chhabra, M.B. and Samantaray, S. 2013. Sarcocystis and sarcocystosis in India: status and emerging perspectives. $J$. Parasit. Dis., 37(1): 1-10.

Du, Q. and Wang, D. 2003. Tetrahedral mesh generation and optimization based on centroidal Voronoi tessellations. Int. J. Numer. Meth. Eng., 56(9): 1355-1373.

Erkens, T., Van Poucke, M., Vandesompele, J., Goossens, K., Van Zeveren, A. and Peelman, L.J. 2006. Development of a new set of reference genes for normalization of real-time RTPCR data of porcine backfat and longissimus dorsi muscle, and evaluation with PPARGC1A. BMC Biotechnol., 6(1): 41.

Giordani, J., Bajard, L., Demignon, J., Daubas, P., Buckingham, M. and Maire, P. 2007. Six proteins regulate the activation of Myf5 expression in embryonic mouse limbs. PNAS, 104(27): 11310-11315.

Hwang, Y. H., Kim, G.D., Jeong, J.Y., Hur, S.J. and Joo, S.T. 2010. The relationship between muscle fiber characteristics and meat quality traits of highly marbled Hanwoo (Korean native cattle) steers. Meat Sci., 86(2):456-461.

Kassar-Duchossoy, L., Gayraud-Morel, B., Gomès, D., Rocancourt, D., Buckingham, M., Shinin, V., and Tajbakhsh, S. 2004. Mrf4 determines skeletal muscle identity in Myf5: Myod double-mutant mice. Nature, 431(7007): 466-471.

Kaur, M., Kumar, A., Siddaraju, N. K., Fairoze, M. N., Chhabra, P., Ahlawat, S. and Arora, R. 2020. Differential expression of miRNAs in skeletal muscles of Indian sheep with diverse carcass and muscle traits. Sci. Rep., 10(1): 1-11.
Kim, D.C., Seo, S., Ahn, S.E., Suh, D.S., Lee, M.J., Park, B. H. and Lee, J.E. 2006. Electrical observations of filamentary conductions for the resistive memory switching in $\mathrm{NiO}$ films. Appl. Phys. Lett., 88(20): 202102.

Maak, T. and Pless, N.M. 2006. Responsible leadership in a stakeholder society-a relational perspective. J. Bus. Ethics, 66(1): 99-115.

Mesires, N.T. and Doumit, M.E. 2002. Satellite cell proliferation and differentiation during postnatal growth of porcine skeletal muscle. Am. J. Physiol. Cell Physiol., 282(4): C899-C906.

Op’t Eijnde, B., Ursø, B., Richter, E. A., Greenhaff, P. L., and Hespel, P. 2001. Effect of oral creatine supplementation on human muscle GLUT4 protein content after immobilization. Diabetes, 50(1): 18-23.

Patruno, M., Caliaro, F., Maccatrozzo, L., Sacchetto, R., Martinello, T., Toniolo, L., and Mascarello, F. 2008. Myostatin shows a specific expression pattern in pig skeletal and extraocular muscles during pre-and post-natal growth. Differentiation, 76(2): 168-181.

Ropka-Molik, K., Eckert, R., and Piórkowska, K. 2011. The expression pattern of myogenic regulatory factors $M y o D$, Myf6 and Pax 7 in postnatal porcine skeletal muscles. Gene Expr. Patterns, 11(1-2): 79-83.

Rozen, S., and Skaletsky, H. 2000. Primer3 on the WWW for general users and for biologist programmers. Curr. Protoc. Bioinformatics, 365-386.

Sodhi, S.S., Song, K.D., Ghosh, M., Sharma, N., Lee, S.J., Kim, J.H. and Jeong, D.K. 2014. Comparative transcriptomic analysis by RNA-seq to discern differential expression of genes in liver and muscle tissues of adult Berkshire and Jeju Native Pig. Gene, 546(2): 233-242.

Sulabh, S., Shivhare, P., Kumari, A., Kumar, M. and Nimmanapalli, R. 2017. Status of pig rearing in India. Int. J. Vety. Sci. Ani. Husband., 2(3): 30-32.

te Pas, A.B. and Walther, F.J. 2007. A randomized, controlled trial of delivery-room respiratory management in very preterm infants. Pediatr., 120(2): 322-329.

White, R.B., Biérinx, A.S., Gnocchi, V.F. and Zammit, P.S. 2010. Dynamics of muscle fibre growth during postnatal mouse development. BMC Dev. Biol., https://doi.org/10.1186/1471213X-10-21.

Wyszyńska-Koko, J., and Kurył, J. 2004. Porcine MYF6 gene: sequence, homology analysis, and variation in the promoter region. Anim. Biotechnol., 15(2): 159-173.

Xu, Y., Shi, T., Zhou, Y., Liu, M., Klaus, S., Lan, X., Lei, C., and Chen, Hong. 2018. A novel PAX7 10-bp indel variant modulates promoter activity, gene expression and contributes to different phenotypes of Chinese cattle. Sci. Rep., 8: 1724. 
Yang, S.Y., Ryu, I., Kim, H.Y., Kim, J.K., Jang, S.K. and Russell, T.P. 2006. Nanoporous membranes with ultrahigh selectivity and flux for the filtration of viruses. Adv. Mater, 18(6): 709712 .
Yin, H., Price, F. and Rudnicki, M.A. 2013. Satellite Cells and the Muscle Stem Cell Niche. Physiol. Rev., 93(1): 23-67. 
